\title{
KARAKTERISTIK MASYARAKAT MUSLIM KOTA SAMBAS DALAM MENENTUKAN ARAH KIBLAT UNTUK PELAKSANAAN SALAT DI RUMAH
}

\author{
Reza Akbar \\ Fakultas Syariah Institut Agama Islam Sultan Muhammad Syafiuddin Sambas \\ reza akbar34@yahoo.com
}

\begin{abstract}
Abstrak
Kepastian tentang arah kiblat tidak banya diperlukean bagi sebuah masjid saja, melainkan diperlukan pula di tempattempat seperti rumah, pusat perbelanjaan, perkantoran, dan tempat-tempat lain. Salat di rumah tentu tidak dapat dibindarkan baik bagi seorang muslim laki-laki maupun wanita karena beberapa kondisi yang menghendaki seseorang mesti melakukannya. Tentu tidak semua masyarakat mampu menentukan arab kiblat secara tepat ketika melaksanakan salat di rumah disebabkan berbagai faktor. Penelitian ini bertujuan untuk mengetabui karakteristik masyarakat Kota Sambas dalam menentukan arah kiblat untuk, pelaksanaan salat di rumah. Jenis penelitian ini merupakan penelitian kualitatif lapangan yang menerapkan teori grounded dan datanya diperoleb dari hasil wawancara. Adapun hasil penelitian ini adalab bahwa karakteristik masyarakat Kota Sambas Kalimantan Barat dalam penentuan arab kiblat untuk. pelaksanaan salat di rumah adalab: pertama, penentuan arah kiblat umumnya masih menggunakan perkiraan arah masjid terdekat. Kedua, pada umumnya, masyarakat tidak memberikan tanda kbusus seperti garis atau tanda anak. panah sebagai petunjuk, arah kiblat di rumah. Ketiga, secara umum, masyarakat Kota Sambas dalam menentukan arah kiblat masib menggunakan dugaan karena sebagian besar tidak diberi tanda khusus dan menggunakan arah kiblat masjid terdekat.
\end{abstract}

Kata Kunci: Arab Kiblat, Salat, Kota Sambas.

\begin{abstract}
Certainty about the Qibla direction is not only needed for a mosque, but is also needed in places such as homes, shopping centers, offices, and other places. Prayers at home certainly cannot be avoided for both a Muslim male and female because of some conditions that require someone to do it. Of course not all people are able to determine the Qibla direction appropriately when carrying out prayers at home due to various factors. This study aims to determine the characteristics of the Muslim Society of Sambas City in determining the Qibla direction for the implementation of prayers at home. This type of research is a qualitative field research that applies grounded theory and the data are obtained from interviews. The results of this study are that the characteristics of the people of Sambas City, West Kalimantan in determining the Qibla direction for the implementation of prayers at home are: first, the determining the Qibla direction generally still uses the approximate direction of the nearest mosque. Second, in general, the society does not provide special signs such as lines or arrows as qibla directions at home. Third, in general, the people of S ambas City in determining the Qibla direction still use suspicion because most are not given special marks and use the direction of the nearest mosque Qibla.
\end{abstract}

Keywords: Qibla direction, prayer, Sambas City.

\section{PENDAHULUAN}

Menghadap kiblat adalah salah satu syarat sah dalam melaksanakan proses ibadah salat seperti yang dicontohkan rasululah Muhammad saw. Artinya, seseorang tidak dianggap sah salatnya apabila melaksanakan salat tanpa menghadap kiblat, kecuali dalam beberapa hal misalnya salat dalam keadaan takut, dan salat di atas kendaraan (Marwadi, 2014). Hal ini dijelaskan di dalam alQuran surat al-Baqarah ayat 144 yang artinya "Sungguh Kami (sering) melihat mukamu menengadah ke langit, Maka sungguh Kami akan memalingkan kamu ke kiblat yang kamu sukai. Palingkanlah mukamu ke arah Masjidil Haram. dan dimana saja kamu berada, Palingkanlah mukamu ke arahnya. dan Sesunggubnya orang-orang (Yabudi dan Nasrani) yang diberi Al kitab (Taurat dan Injil) memang mengetahui, bahwa berpaling ke Masjidil Haram itu adalab benar dari Tuhannya; dan Allab sekali-kali tidak lengah dari apa yang mereka kerjakan." Menurut Al-Râzî, kiblat ke masjidil haram ini merupakan pilihan yang paling disukai rasulullah yang semula di baitul maqdis dialihkan ke 
masjidil haram (Râzi, tt). Dengan demikian, bagi orang yang mukim, wajib baginya untuk mengikuti seperti yang dicontohkan rasulullah pada saat melaksanakan salat yakni mengetahui arah kiblat dengan berbagai cara baik dengan menentukannya sendiri maupun meminta bantuan kepada orang yang ahli.

Kepastian tentang arah kiblat tidak hanya diperlukan bagi sebuah masjid saja. Selain masjid, arah kiblat juga diperlukan di tempat-tempat lain seperti rumah, pusat perbelanjaan, dan perkantoran atau di tempat-tempat umum yakni di mana saja seseorang dapat melaksanakan salat. Untuk ketentuan arah kiblat di rumah, selain digunakan untuk melaksanakan salat dengan khusyu', arah kiblat juga sangat penting untuk panduan pembuatan toilet agar tidak menghadap atau membelakangi kiblat saat digunakan. Mengenai boleh tidaknya menghadap atau membelakangi kiblat ketika bertoilet, terdapat dua pendapat. Jumhur ulama yaitu Imam Malik, Imam Syafii dan Imam Ahmad berpendapat bahwa larangan tersebut hanya berlaku bagi orang-orang yang bertoilet di tempat terbuka di mana tidak ada penghalang antara dirinya dengan kiblat (Kakbah). Adapun di dalam bangunan, dibolehkan bertoilet walaupun dalam keadaan menghadap atau membelakangi kiblat karena terdapat penghalang antara dirinya dengan kiblat (Kakbah). Sedangkan ulama lainnya seperti Abu Hanifah yang juga diikuti oleh Syaikhul Islam Ibnu Taimyiah berpendapat diharamkannya menghadap atau membelakangi kiblat saat bertoilet secara mutlak, baik di tempat terbuka atau di dalam bangunan (Al-Munajjid, 2019).

Salat di rumah tidak dapat dihindarkan baik bagi seorang muslim laki-laki maupun wanita karena beberapa kondisi yang menghendaki seseorang mesti melakukannya. Misalnya, bagi seorang wanita, salat di rumah justru lebih utama dibandingkan dengan salat di masjid berdasarkan sebuah hadis yang diriwayatkan oleh Abu Dawud dari Ibnu Umar. Seorang laki-laki juga sering harus melaksanakan salat di rumah karena beberapa kondisi seperti melaksanakan salat sunnah. Tidak jarang pula seorang laki-laki melaksanakan salat wajib di rumah karena beberapa hal seperti kondisi cuaca, jarak yang cukup jauh dari masjid, sakit, dan lain sebagainya. Dengan kondisi yang demikian, kepastian akan arah kiblat di rumah menjadi mutlak diperlukan yang penentuannya membutuhkan keakuratan sebagaimana kepastian arah kiblat di masjid agar pelaksanaannya menjadi lebih khusyu'.

Ada kebiasaan masyarakat yang menghadap kiblat dengan cara menduga-duga ketika mereka melaksanakan salat di rumah. Berdasarkan survei awal yang dilakukan peneliti, kebanyakan rumah memang belum ditentukan arah kiblatnya sehingga pelaksanaan salat di rumah menerapkan cara menduga-duga mengenai arah kiblat. Hal ini ditandai dengan arah kiblat yang ada di rumah kebanyakan umat muslim belum diukur atau ditentukan dengan teknik tertentu. Selain itu, cara menduga-duga arah kibat di rumah juga ditandai dengan belum adanya tanda khusus (misalnya anak panah kiblat) yang menunjukkan kepastian arah kiblat. Arah kiblat yang digunakan adalah arah kiblat sesuai dengan dugaan yang disesuaikan dengan arah masjid terdekat dengan tempat tinggal.

Sebagian besar penduduk Kabupaten Sambas Kalimantan beragama Islam. Di Kalimantan Barat, jumlah penduduk yang beragama Islam mencapai 59,72\% (Dukcapil, 2018). Sedangkan dalam masyarakat Sambas, jumlah penduduk muslim di Kabupaten ini terbilang sangat besar hingga mencapai 84,82\% (Wikipedia, 2019). Besarnya jumlah penduduk yang beragama Islam ini tidak terlepas dari sebagian besar penduduknya merupakan suku Melayu. Sedangkan suku Melayu sendiri merupakan suku yang melekat padanya identitas Islam yang sangat kuat, yang membedakan suku Melayu dengan suku-suku lainnya. Hal ini disebabkan karena adanya pepatah adat yang menyebutkan "syarak mengata adat memakai", yang mengandung arti bahwa adat merupakan operasional dari nilai nilai Islam (Muslim, 20171).

Saat ini cukup banyak aplikasi berbasis smart phone yang dapat digunakan untuk menunjuk arah kiblat seperti aplikasi kiblat dan waktu sholat, Kiblat Visual, Qibla, dan lain-lain. Ini cukup praktis dilakukan oleh siapa pun. Hanya saja masyarakat belum terbiasa untuk menentukan arah kiblat dengan cara seperti ini karena umumnya tidak diketahui khususnya oleh kalangan orang-orang tua. Sejauh yang penulis amati, aplikasi penunjuk arah kiblat tergolong akurat karena penunjukan oleh aplikasi-aplikasi tersebut sama dengan hasil pengamatan di lapangan yang berbasis perhitungan.

Penelitian ini bertujuan untuk mengetahui karakteristik masyarakat muslim Sambas dalam menghadap kiblat ketika melaksanakan salat di 
rumah. Sejauh penelusuran yang dilakukan peneliti, belum ada penelitian yang serupa baik berdasarkan fokus penelitian maupun lokasinya. Penelitian ini diharapkan dapat bermanfaat bagi pihak-pihak yang berwenang untuk menyosialisasikan pemecahan yang dihadapi masyakat apabila temuan penelitian ini menunjukkan perlunya media yang dapat membantu masyarakat dalam menentukan arah kiblat di rumah tanpa menduga-duga. Dengan demikian, penelitian ini menjadi signifikan untuk dilakukan.

\section{METODE}

Penelitian ini merupakan penelitian kualitatif lapangan karena merupakan penelitian yang datanya bukan berupa angka-angka. Adapun jenis penelitiannya termasuk penelitian teori grounded yang merupakan salah satu jenis penelitian kualitatif di mana peneliti akan menarik generalisasi dari apa yang diamati secara induktif, teori yang abstrak tentang tindakan berdasarkan pandangan dari partisipan yang diteliti (Sugiyono, 2017). Adapun generalisasi atau proses penarikan kesimpulan secara induktif di dalam penelitian ini adalah mengenai fenomena sosial yang terjadi di dalam masyarakat muslim Kota Sambas dalam menghadap kiblat untuk pelaksanaan salat di rumah. Fenomena yang menjadi data penelitian secara umum adalah cara masyarakat muslim di Kota Sambas menentukan arah kiblat untuk pelaksanaan salat di rumah. Dengan demikian, sumber data penelitian ini merupakan data primer yaitu data yang diambil secara langsung oleh peneliti di lapangan. Adapun pengambilan data di dalam penelitian ini menggunakan teknik wawancara (interview) dengan model pertanyaan terstruktur dengan jenis pertanyaan tertutup dan terbuka. Kombinasi jenis pertanyaan tertutup dan terbuka disebabkan jawaban yang akan diberikan responden memiliki banyak kemungkinan.

Adapun lokasi penelitian ini adalah Kota Sambas Kalimantan Barat. Pemilihan Kota Sambas sebagai lokasi penelitian disebabkan karena Kota Sambas termasuk kota yang dikenal agamis religious yang ditandai dengan adanya simbolsimbol Islam di tengah-tengah kota seperti nama jalan dan nama-nama asmaul husna. Selain itu, Kota Sambas termasuk kota di mana masjid sangat mudah ditemukan karena sebagian besar penduduknya beragama Islam. Kota Sambas yang dimaksud di dalam penelitian ini adalah Ibu Kota
Kabupaten Sambas Kalimantan Barat yang termasuk kawasan perkotaan menurut klasifikasi Badan Pusat Statistik (BPS) yang terdiri dari 10 desa yaitu Desa Durian, Desa Pasar Melayu, Desa Pendawan, Desa Tanjung Bugis, Desa Lubuk Dagang, Desa Dalam Kaum, Desa Tanjung Mekar, Desa Tumuk Manggis, Desa Jagur, dan Desa Lorong (Badan Pusat Statistik, 2010). Dengan demikian, populasi dari penelitian ini adalah seluruh rumah penduduk yang beragama Islam di desa-desa tersebut. Oleh karena jumlah populasi sangat banyak, peneliti menentukan titik-titik lokasi penelitian yakni dengan memilih secara acak beberapa informan muslim di setiap desa di Kecamatan Sambas yang termasuk wilayah perkotaan. Dalam proses pengambilan data, peneliti melihat kecenderungan data sehingga ketika data sudah menunjukkan kejenuhannya, saat itulah peneliti dapat menarik generalisasi secara induktif. Hasil dari penelitian ini menghasilkan sebuah teori di bidang sosial yakni karakteristik masyarakat muslim Kota Sambas dalam menentukan arah kiblat untuk pelaksanaan salat di rumah.

\section{HASIL DAN PEMBAHASAN}

\section{PROFIL KOTA SAMBAS DAN KEHIDUPAN MASYARAKATNYA}

Sambas adalah sebuah kecamatan sekaligus ibu kota Kabupaten Sambas, Kalimantan Barat. Secara geografis, Kota Sambas terletak hampir di tengah-tengah wilayah Kabupaten Sambas. Kota Sambas sebenarnya mengacu pada Kecamatan Sambas. Secara astronomis, Kecamatan Sambas

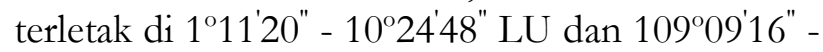
$109^{\circ} 26^{2} 23^{\prime \prime} \mathrm{BT}$, dengan luas sekitar 246,56 km². Wilayah Kecamatan Sambas mencakup sekitar 0,64\% dari wilayah Kabupaten Sambas (Wikipedia, 2019).

Menurut BPS yang tercantum dalam Peraturan Kepada Badan Pusat Statistik Nomor 37 Tahun 2010 Tentang Klasifikasi Perkotaan dan Perdesaan di Indonesia, Kecamatan Sambas diklasifikasikan ke dalam wilayah perkotaan dan perdesaan. Dari kasifikasi BPS ini, dapat disimpulkan bahwa Kota Sambas saat ini adalah wilayah Kecamatan Sambas yang termasuk ke dalam kategori perkotaan. 
Tabel 1. Klasifikasi Perdesaan dan Perkotaan Kecamatan Sambas (Badan Pusat Statistik, 2010)

\begin{tabular}{lll}
\hline No & Nama Desa & Klasifikasi \\
\hline 1. & Sei Rambah & Perdesaan \\
\hline 2. & Gapura & Perdesaan \\
\hline 3. & Kartiasa & Perdesaan \\
\hline 4. & Saing Rambi & Perdesaan \\
\hline 5. & Lumbang & Perdesaan \\
\hline 6. & Durian & Perkotaan \\
\hline 7. & Pasar Melayu & Perkotaan \\
\hline 8. & Pendawan & Perkotaan \\
\hline 9. & Tanjung Bugis & Perkotaan \\
\hline 10. & Lubuk Dagang & Perkotaan \\
\hline 11. & Dalam Kaum & Perkotaan \\
\hline 12. & Tanjung Mekar & Perkotaan \\
\hline 13. & Tumuk Manggis & Perkotaan \\
\hline 14 & Jagur & Perkotaan \\
\hline 15. & Lorong & Perkotaan \\
\hline 16. & Sebayan & Perdesaan \\
\hline 17. & Sumber Harapan & Perdesaan \\
\hline 18. & Semangau & Perdesaan \\
\hline
\end{tabular}

Secara historis, orang yang pertama membuka dan mengembangkan Kota Sambas adalah Sultan Muhammad Tajuddin I yang dikenal sebagai Raden Bima sebagai Sultan Sambas yang kedua. Pada sekitar tahun 1683 M, ia memindahkan pusat pemerintahan Kesultanan Sambas dari Lubuk Madung ke Muare Ulakkan yaitu persimpangan dari tiga Sungai Sambas, Sungai Teberau, dan Sungai Subah, yang kemudian berkembang menjadi Kota Sambas sekarang ini (Wikipedia, 2019).

Masyarakat Kota Sambas didominasi oleh Suku Melayu, yaitu Melayu Sambas. Namun, terdapat pula suku lainnya seperti Tionghoa yang secara dominan menempati wilayah pasar Kota Sambas. Suku-suku lain juga berbaur dengan masyarakat setempat seperti Dayak, Jawa, Bugis, dan lain-lain. Adapun bahasa sehari-hari yang digunakan adalah Bahasa Melayu Sambas dengan kekhasan tersendiri, yaitu pada pengucapan huruf 'e' seperti kata 'lélé' di dalam bahasa Indonesia. Keunikan lain dari bahasa Melayu Sambas adalah pengucapan huruf ganda, seperti pada kata bassar (besar dalam bahasa Indonesia), kaccik (kecil dalam bahasa Indonesia), gille (gila dalam bahasa Indonesia), dan lain sebagainya.

Kota Sambas menyimpan warisan sejarah yang sangat berharga berupa sebuah Keraton Kesultanan Sambas (Istana Alwatsikoebillah) yang terletak di tepi Muara Ulakan, Desa Dalam Kaum. Di dalam keraton tersebut, tersimpan koleksi bersejarah masa Kesultanan Sambas seperti pakaian kesultanan, meriam, cermin besar, tempat tidur sultan, dan dokumentasi. Beberapa di antaranya masih dikeramatkan oleh pihak keraton.

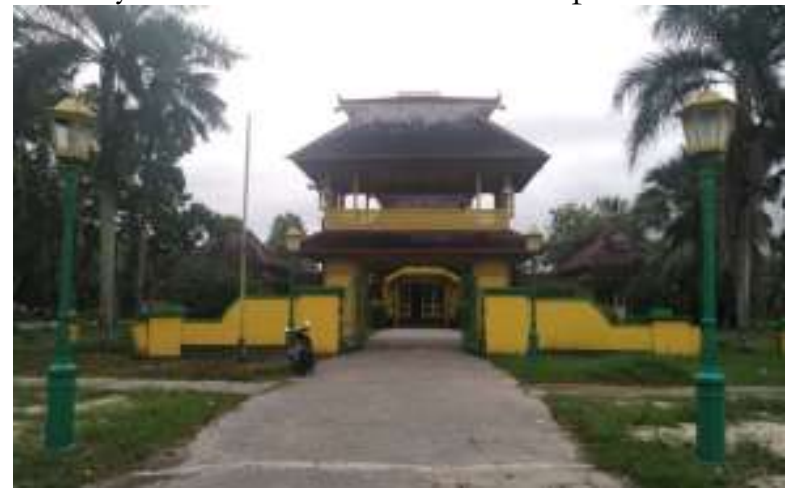

Gambar 1. Keraton Kesultan Sambas

Di dekat keraton, berdiri pula sebuah masjid yang dikenal sebagai Masjid Jami’ Sambas. Masjid Jami' ini cukup unik karena terbuat dari bahan kayu/papan. Arah kiblat masjid ini juga sudah mengalami perubahan sudut yang cukup signifikan dari bangunan asli sehingga arah hadapan masjid tidak sejajar dengan arah salat para jamaah. Kedua tempat ini menjadi tempat wisata yang sering dikunjungi baik oleh wisatawan dari dalam Kota Sambas maupun wisatawan luar.

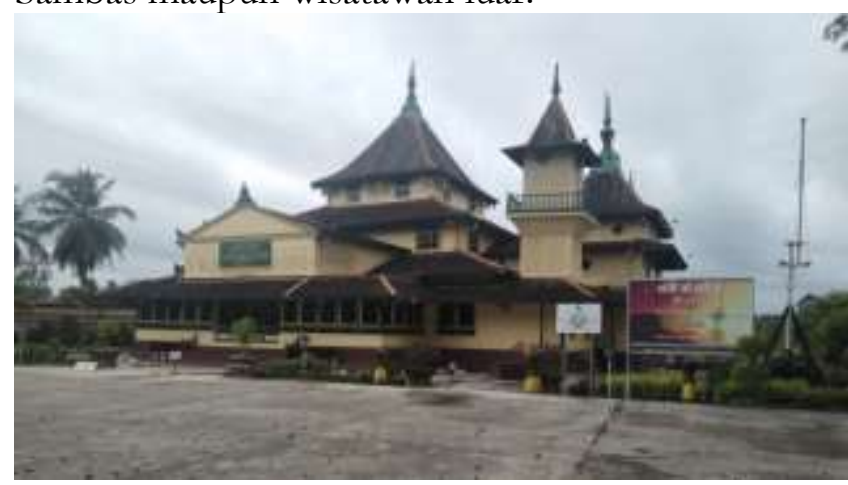

Gambar 2. Keraton Kesultanan Sambas

Ciri khas lainnya dari Kota Sambas adalah masyarakatnya yang agamis religius. Secara fisik, hal ini tercermin dalam penamaan jalan/gang yang ditulis di dalam bahasa Arab. Selain itu, di sepanjang jalan pusat perkantoran (Jalan Pembangunan), dipasang pula nama-nama Allah atau asmaul husna. Pada masa lalu, masyarakat Melayu Sambas terkenal agamis sehingga sempat disebut sebagai Serambi Makekah Kalimantan Barat. Pada masa itu, ulama-ulama Islam dari Kesultanan Sambas sangat terkemuka dan telah berkaliber internasional, misalnya pada abad ke-19 M ada seorang ulama Kesultanan Sambas yang bernama 
Sheikh Khatib Achmad As-Sambasi yang menjadi ulama di Makkah dan menjadi pemimpin ulamaulama di Nusantara yang menuntut ilmu agama di sana dengan gelar Shekh Sharif Kamil Mukammil. Kemudian pada abad ke-20 M, ada pula ulama Kesultanan Sambas yang bernama Shekh Muhammad Basuni Imran yang merupakan lulusan Al-Azhar Kairo, Mesir yang terkenal di Timur Tengah karena suratnya kepada Mufti Mesir yang berjudul Mengapa Umat Islam saat ini Mengalami Kemunduran? (Wikipedia, 2019)

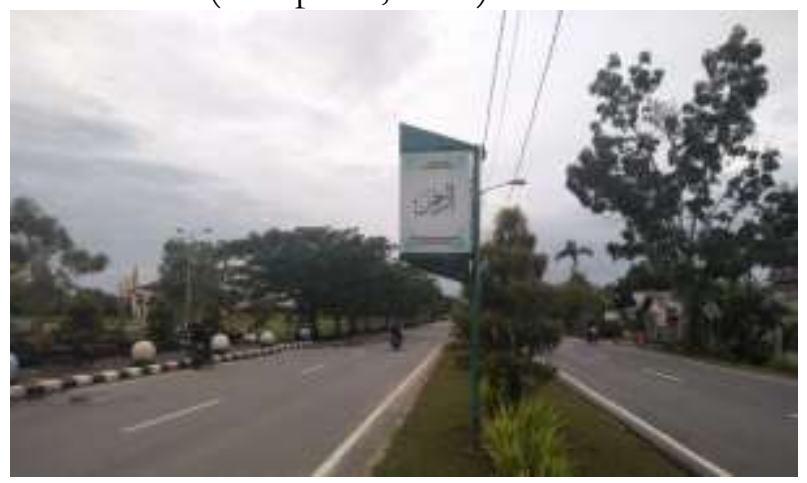

Gambar 3. Hiasan asmaul husna di Jalan Pembangunan Kota Sambas

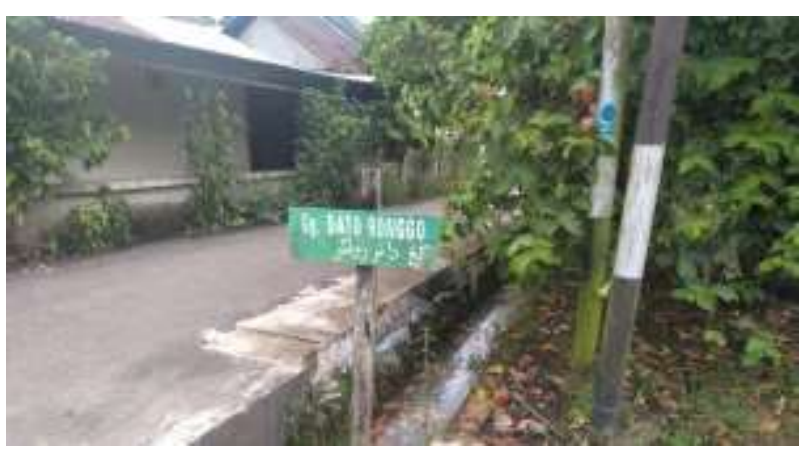

Gambar 4. Salah satu nama gang yang bertuliskan Arab

\section{PENGERTIAN ARAH KIBLAT}

Kiblat berasal dari bahasa Arab yang artinya adalah arah yang merujuk ke suatu tempat dimana bangunan Ka'bah di Masjidil Haram, Makkah, Arab Saudi. Ka'bah juga sering disebut dengan Baitullah (Rumah Allah). Menghadap arah Kiblat merupakan suatu yang penting dalam syariat Islam. Menurut hukum syariat, menghadap ke arah kiblat diartikan sebagai seluruh tubuh atau badan seseorang menghadap ke arah Ka'bah yang terletak di Makkah yang merupakan pusat tumpuan umat Islam bagi menyempurnakan ibadah-ibadah tertentu (RHI, 2019).
Ketentuan arah kiblat adalah arah sudut ke Masjidil Haram yang merupakan ketertiban bagi umat Islam dalam menjalankan ibadah salat (Raharto \& Surya, 2011). Dalam sebuah hadis dha'if, disebutkan ketentuan menghadap kiblat bagi umat Islam yaitu sebuah hadis dari Ibn 'Abbâs (Baihaqi>, 2003):

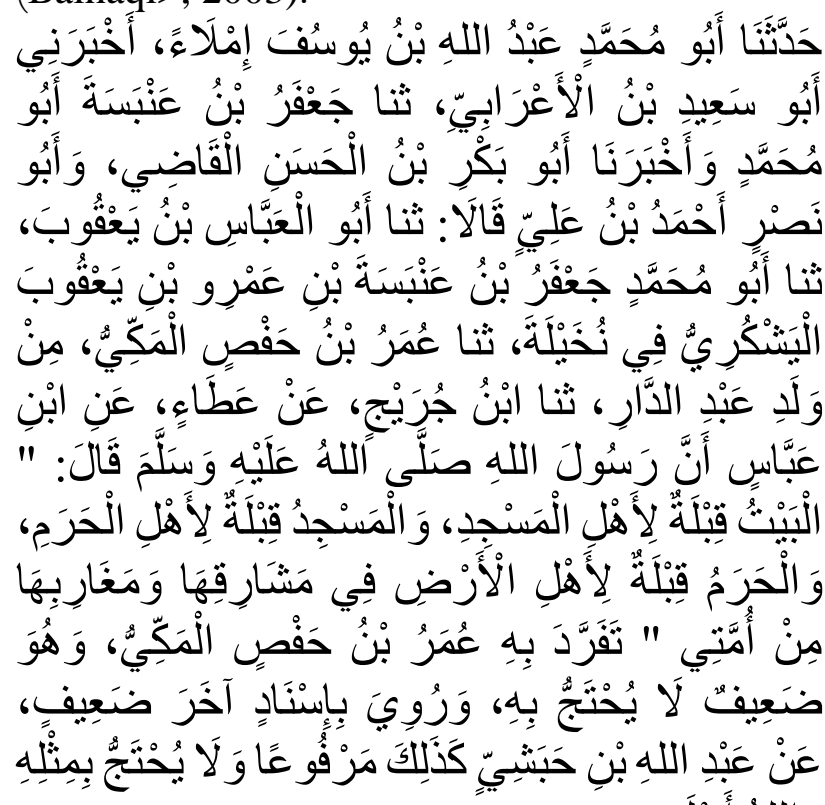

وَ اللاهُ أَعْلَحَُ عَدْ

Arti dari matan hadis di atas adalah:

"Ka'bah adalah kiblat bagi orangyang salat di Masjidil Haram, dan Masjidil Haram adalah kiblat bagi penduduk yang tinggal di tanah haram, dan tanah haram adalab kiblat bagi penduduk Bumi di timurnya dan dibaratnya dari umatku" (Kementrian Agama RI, 2017)

Bagi umat Islam yang mampu melihat Ka'bah, menghadap kiblat merupakan perkara yang mudah. Akan tetapi, bagi umat Islam yang jauh dari Ka'bah, seperti di Indonesia dan sekitarmya, penentuan arah kiblat membutuhkan metode tertentu agar dapat mengarahkan kiblatnya dengan kekakuratan yang baik. Menghadap kiblat (istiqbal al-qiblah) berarti menghadap ke suatu arah di mana arah tersebut merupakan arah terdekat menuju Kakbah. Lawan menghadap yakni membelakangi Kakbah (istidbar al-qiblah). Jika Bumi dipandang sebagai sebuah bola sempurna maka ketika menghadap ke arah kiblat secara bersamaan seseorang sebenarnya juga membelakangi kiblat. Hanya saja, konsep menghadap di bidang bola adalah jarak terdekat dari seseorang ke Kakbah yaitu melalui lingkaran besar (great circle). 
Berdasarkan metodenya, ada dua cara yang dapat dilakukan untuk menentukan arah kiblat yaitu sebagai berikut.

1. Berdasarkan perhitungan

a. Perhitungan menggunakan rumus segitiga bola (spherical trigonometry)

Penggunaan rumus segitiga bola dalam penentuan arah kiblat adalah dengan mengkombinasikan rumus sinus dan cosinus. Titik A (Ka'bah) memiliki koordinat bujur $\lambda^{k}$ dan lintang $\Phi^{k}$. Titik B merupakan tempat yang akan diukur arah kiblatnya yang memiliki koordinat bujur $\lambda^{x}$ dan lintang $\Phi^{x}$ yang nilainya dapat ditentukan dengan alat GPS (global Positioning System). Titik C merupakan kutub utara yang memiliki lintang 90 derajat. Sudut $C$ tidak lain adalah selisih antara bujur Ka'bah dan bujur tempat. Sementara sudut B adalah arah menuju titik A (Ka'bah).

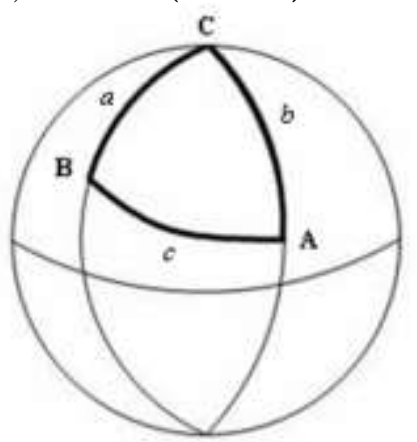

Gambar 5. Segitiga bola $A B C$ yang menghubungkan titik A (Ka'bah), titik B

(tempat) dan titik C (kutub Utara)

Arah kiblat adalah arah terdekat menuju kakbah melalui lingkaran besar (great cyrcle) bumi. Lingkaran bola bumi yang dilalui oleh arah kiblat dapat disebut lingkaran kiblat. Lingkaran kiblat dapat didefinisikan sebaai lingkaran bola bumi yang melalui sumbu atau poros kiblat (Hambali, 2013). Dengan demikian, arah kiblat dari belahan bumi manapun akan dapat ditentukan arahnya berdasarkan teori segitiga bola dengan mempertemukan tiga lingkaran besar yang saling berpotongan, yaitu lingkaran bujur tempat, lingkaran bujur kakbah dan lingkaran yang memotong kedua lintang (tempat dan kakbah).

Dari Gambar di atas, dapat dipahami bahwa segitiga bola ABC menghubungkan antara tiga titik, yaitu A (Ka'bah), titik B (tempat) dan titik C (Kutub Utara). Ketiga titik tersebut dalam bola bumi menetukan letak geografis suatu tempat. Titik-titik tersebut dihasilkan oleh perpotongan garis bujur dan lintang yang tepat berada di titik tersebut.

Lintang tempat yaitu garis vertikal yang mengukur sudut antara suatu titik dengan khatulistiwa (Hambali, 2012). Lintang diukur dari garis khatulistiwa ke arah kutub bumi (dari khatulistiwa ke suatu tempat). Lintang tempat yang berada di sebelah utara khatulistiwa disebut dengan lintang utara dengan tanda $(+)$. Sedangkan lintang yang berada di sebelah selatan khatulistiwa disebut dengan lintang selatan dengan tanda (-). Karena besar sudut ini ditentukan dari khatulistiwa $\left(0^{\circ}\right)$, maka besaran maksimal suatu lintang memiliki nilai 90 derajat, yaitu berada di kutub. Wilayah lintang utara mulai dari $0^{\circ}$ smpai $90^{\circ}$. Adapun wilayah lintang selatan dimulai dari $0^{\circ}$ sampai dengan $-90^{\circ}$.

Adapun persamaan arah kiblat yang sering digunakan adalah:

$\operatorname{cotan} B=(\cot b \sin a): \sin C-\cos a \operatorname{cotan} C$

Dengan keterangan: $\mathrm{a}=90-\varphi^{x}, \mathrm{~b}=90-$ $\varphi^{k}, \operatorname{dan} \mathrm{C}=\lambda^{x}-\lambda^{k}$

b. Perhitungan menggunakan formula Vincenty

Metode Vincenty ini termasuk metode yang memiliki algoritma cukup panjang dan iteratif (bersifat berulang-ulang sampai ketelitian yang tinggi). Metode ini diakui paling akurat dibandingkan dengan metode segitiga bola karena telah memperhitungkan bentuk Bumi sesuai dengan penemuan sains modern yaitu dengan asumsi bentuk Bumi ellipsoid. Adapun formula yang digunakan adalah sebagai berikut.

$a, b=$ setengah sumbu panjang (mayor) dan setengah sumbu pendek (minor)

$f=$ pemepatan (flattening) yang dihitung dengan cara $f=\frac{(a-b)}{a}$

$\phi_{1}, \phi_{2}=$ posisi lintang (latitude) titik 1 dan titik 2

$U_{1}=\arctan \left[(1-f) \tan \phi_{1}\right]=$ nilai lintang titik 1 pada bola pembantu $U_{2}=\arctan \left[(1-f) \tan \phi_{2}\right]=$ nilai lintang titik 2 pada bola pembantu 
$L=L_{2}-L_{1}=$ selisih bujur (longitude) antara dua titik

$\lambda_{1}, \lambda_{2}=$ bujur titik 1 dan bujur titik 2 pada bola pembantu

$\alpha_{1}, \alpha_{2}=$ azimuth titik 1 terhadap titik 2 dan sebaliknya

Adapun rumus azimuth antara dua titik pada permukaan ellipsoid berdasarkan formula Vincenty adalah sebagai berikut (Vincenty, 1975).

$$
=\frac{\tan \alpha_{2}}{\cos U_{1} \sin L}
$$

iterasi mulai dari $L_{0}, L_{1}, L_{2}, d s t$ sampai selisih nilai $L_{n}$ dan $L_{n-1}$ nol (mendekati nol atau berorde sangat kecil misalnya orde10$\left.{ }^{12}\right)$. Adapun menghitung nilai $L$ adalah sebagai berikut.

$\cos \sigma=\sin U_{1} \sin U_{2}+$ $\cos U_{1} \cos U_{2} \cos L_{0}$

$\sin \sigma=$ $\sqrt{\left(\cos U_{2} \sin L_{0}\right)^{2}+\left(\cos U_{1} \sin U_{2}-\sin U_{1} \cos U_{2} \text { cossh } b_{2}\right)^{2}}$ ang terkena paparan sinar Matahari. $\sigma=\tan ^{-1}\left(\frac{\sin \sigma}{\cos \sigma}\right)$

$\sin \alpha=\frac{\cos U_{1} \cos U_{2} \sin L_{0}}{\sin \sigma}$

$\cos ^{2} \alpha=1-\sin ^{2} \alpha$

$\cos (2 \sigma m)=\cos \sigma-\frac{2 \sin U_{1} \sin U_{2}}{\cos ^{2} \alpha}$

$C=\frac{f}{16} \cos ^{2} \alpha\left[4+f\left(4-3 \cos ^{2} \alpha\right)\right]$

$L_{1}=L_{0}+(1-C) f \sin \alpha(\sigma+$

$C \sin \sigma(\cos (2 \sigma m)+C \cos \sigma(-1+$

$\left.\left.2 \cos (2 \sigma m)^{2}\right)\right)$ ) (Fatahillah, 2017).

2. Berdasarkan pengamatan

Penentuan arah kiblat dengan pengamatan adalah penentuan arah kiblat dengan mengamati bayangan benda yang tegak di mana pada saat itu bayangan benda tersebut mengarah ke Kakbah. Saat ini biasa disebut sebagai rashdul kiblat global atau istiwa ala'dzam. Saat rashdul kiblat global, pengamat yang akan menentukan arah bayangan Matahari sebagai petunjuk arah kiblat wajib mengetahui waktu yang tepat saat Matahari tepat berada di atas Ka'bah. Untuk mendapatkan waktu yang tepat, diperlukan pula kalibrasi waktu misalnya dengan penyesuaian jam yang digunakan pengamat agar sesuai dengan jam yang ditunjukkan oleh waktu standar. Selain itu, pengamatan bayangan juga tidak dapat dilakukan dengan cara yang sembarangan tanpa memerhatikan posisi tongkat istiwa dan latar tempat jatuhnya bayangan. Apabila posisi tongkat tidak benar-benar tegak atau latar tempat jatuhya bayangan tidak benar-benar rata maka hasil pengamatannya akan menjadi tidak akurat. Di sini jelas bahwa penentuan arah kiblat tidak dapat dilepaskan dari aspek kaidahkaidah saintifik.

Adapun teknik penentuan arah kiblat pada saat terjadinya rashdul kiblat global adalah sebagai berikut (Izzuddin, 2011).

a. Memastikan waktu terjadinya peristiwa rashdul kiblat global yaitu pada tanggal 27 Mei (tahun kabisat) atau 28 Mei (tahun basitah) pada pukul 16:18 WIB dan tanggal 15 Juli (tahun kabisat) atau 16 Juli (tahun basitah) pada pukul 16:27 WIB. Pastikan bahwa jam yang digunakan pengamat benarbenar akurat atau sudah dicocokkan dengan waktu radio atau televisi/internet.

b. Menentukan lokasi yang akan ditentukan arah kiblatnya seperti masjid, mushala, atau

c. Menyediakan tongkat yang benar-benar lurus yang ditempatkan pada bidang yang benar-benar datar (halamasn masjid, rumah, dan lain-lain) sehingga antara bidang dan tongkat terbentuk sudut 90 derajat (tegak lurus). Dapat pula menggunakan papan kecil (papan dial) yang sudah dipasang tongkat seperti perangkat istiwa'aini yang kedataran bidangnya dapat diatur dengan akurat dan mudah menggunakan waterpas.

d. Pada saat waktu menunjukkan pukul terjadinya rashdul kiblat, amati bayangan Matahari dan beri tanda menggunakan spidol dengan cara menggaris atau menggunakan teknik penandaan lain seperti lakban, penggaris yang dapat membuat tanda lurus.

e. Arah kiblat yang terbentuk adalah arah yang langsung menghadap Matahari atau barat serong ke utara.

f. Untuk meluruskan arah kiblat ke dalam masjid/rumah, gunakan tali atau pantulan sinar Matahari.

Sedangkan berdasarkan media yang diamanfaatkan, penentuan arah kiblat dapat diklasifikasikan menjadi dua yaitu: 
a. Manual (Tak Langsung)

Penentuan arah kiblat secara manual adalah penentuan arah kiblat di mana seseorang menentukan sendiri arah kiblat baik yang diawali oleh perhitungan maupun tanpa perhitungan, seperti yang sudah dijelaskan sebelumnya. Kelebihan cara ini adalah seorang praktisi dapat memilih metode perhitungan yang paling akurat kemudian menentukannya dengan alat yang tersedia. Selain itu, hasil pengukuran yang diperoleh dapat dipertanggungjawabkan karena sudah melalui proses perhitungan dan melalui seraangkaian tahapan sesuai kaiadah-kaidah ilmiah. Adapun kelemahan metode ini adalah membutuhkan waktu dan tenaga yang lebih besar.

b. Digital (Langsung)

Sedangkan penentuan arah kiblat secara digital adalah penentuan arah kiblat dengan memanfaatkan aplikasi/software yang tersedia baik melalui smartphone atau pun media online lainnya. Kelebihan cara ini adalah sangat praktis karena arah kiblat langsung dapat diketahui hanya dalam hitungan detik. Namun, cara ini juga memiliki kelemahan. Pertama, pengguna (user) tidak mengetahui algoritma yang digunakan apakah masih menggunakan dasar perhitungan spherical trigonometry atau pun sudah menggunakan formula Vincenty sehingga hasilnya tidak dapat dipertanggungjawabkan secara ilmiah. Kedua, metode ini bergantung pada keadaan sekitar misalnya sinyal yang baik karena di dalam penunjukan arah kiblat oleh aplikasi/software tertentu juga dipengaruhi oleh keadaan sinyal/jaringan yang tersedia.

\section{PENTINGNYA MENGETAHUI ARAH KIBLAT DI RUMAH}

Dengan kemajuan teknologi informasi saat ini, masyarakat sebenarnya dapat dengan mudah untuk memecahkan masalah sehari-hari seperti penentuan arah kiblat, jadwal salat, konversi kalender hijriayah-masehi, dan sebagainya. Hal tersebut disebabkan saat ini sudah tersedia berbagai aplikasi di smartphone yang menyediakan jadwal salat, penentuan arah kiblat, dan lain-lain yang untuk memperolehnya termasuk hal yang mudah, terutama bagi anak-anak muda yang melek teknologi informasi. Bagi orang-orang tua, juga sudah terbiasa menggunakan smartphone, walaupun ada juga kalangan orang tua yang masih belum melek teknologi informasi. Maraknya penggunaan smartphone, baik oleh kalangan muda maupun tua sebenarnya memberikan peluang kepada masyarakat untuk memanfaatkan aplikasi-aplikasi yang bermanfaat bagi pelaksanaan salat, yakni aplikasi penunjuk arah kiblat, tanpa perlu lagi menduga-duga.

Di rumah, setidaknya ada dua alasan mengapa arah kiblat harus ditentukan dengan akurat. Pertama, untuk melaksanakan salat agar lebih khusyu'. Hal ini karena menghadap kiblat merupakan salah satu syarat sahnya ibadah salat. Para ulama sepakat bahwa menghadap kiblat menjadi syarat sahnya salat, tetapi mereka tidak sepakat bahwa orang yang salat wajib menghadap ke bangunan Ka'bah atau ke arah Ka'bah (Marwadi, 2014). Hal ini tentu sulit bagi mereka yang tidak melihat Kakbah. Hanya saja, untuk kesempurnaan ibadah, diperlukan usaha mencari arah kiblat yang tepat, termasuk penentuan arah kiblat secara akurat di rumah.

Kedua, untuk memastikan bahwa toilet yang dibuat di rumah tidak menghadap atau tidak membelakangi kiblat saat digunakan. Di dalam sebuah hadis, rasulullah bersabda:

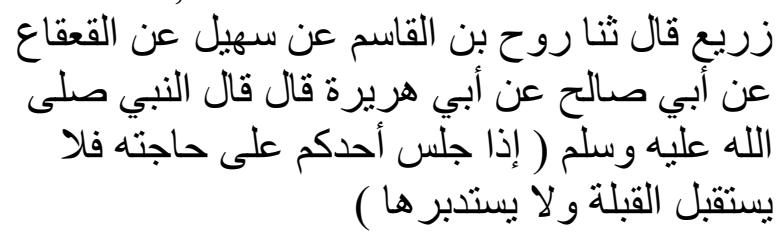

Artinya: "Zarî' berkata: menceritakan kepada kami rûh ibn qâsim dari Sahîl dari al-Qa'qâ' dari Abu Shâlih dari Abû Hurairah berkata, Nabi saw. bersabda: Apabila duduk di antara kalian untuk berhajat (bertoilet) janganlah menghadap kiblat atau membelakanginya" (Abu 'Awânah, tt, Juz 1).

Mengenai persoalan ini, terdapat dua pendapat yang masyhur. Jumhur ulama seperti Imam Malik, Imam Syafii dan Imam Ahmad berpendapat bahwa larangan bertoilet yang dijelaskan oleh sebuah hadis rasulullah, hanya berlaku bagi orang-orang yang bertoilet di tempat terbuka di mana tidak ada penghalang antara pengguna toilet dengan kiblat (Kakbah). Adapun apabila berada di dalam rumah atau bangunan, diperbolehkan bertoilet walaupun dalam keadaan menghadap atau membelakangi kiblat karena terdapat penghalang antara pengguna toilet dengan kiblat (Kakbah). Sedangkan ulama lainnya 
seperti Abu Hanifah yang juga diikuti oleh Syaikhul Islam Ibnu Taimyiah berpendapat bahwa haram hukumnya menghadap atau membelakangi kiblat saat bertoilet secara mutlak, baik di tempat terbuka atau di dalam rumah atau bangunan (Munajjid, 2019).

Secara lebih rinci, ada lima pendapat mengenai hukum buang hajat (bertoilet) yang menghadap atau membelakangi ke kiblat. Pertama, jika tidak ada pemisah antara bangunan dengan Kakbah maka hukumnya makruh. Adapun hadis yang menerangkan hal ini adalah hadis dari Ibnu Umar bahwa ia pernah melihat Rasulullah saw. menunaikan hajatnya menghadap Baitul Maqdis dan membelakangi Kakbah. Kedua, hukumnya adalah haram, yakni berdasarkan makna zahir dari hadis tersebut. Ketiga, hukumnya adalah boleh. Hal ini dikarenakan hadis-hadis yang melarang perbuatan tersebut sudah dicabut (dinasakh) oleh hadis-hadis yang memperbolehkan. Keempat, buang hajat yang menghadap/membelakangi kiblat hukumnya haram apabila di padang pasir tanpa ada bangunan yang menghalangi. Hal ini diperkuat oleh hadis dari Ibnu Umar bahwa ia pernah berkata bahwa pengharaman buang hajat menghadap kiblat hanya berlaku apabila tempat terbuka, jika ada penghalang antara ia dan Kakbah maka hal ini tidaklah apa-apa. Kelima, diharamkan buang hajat (bertoilet) menghadap kiblat. Akan tetapi, diperbolehkan membelakanginya. As-Sya'bi berkata tentang hal ini bahwa sebab dilarangnya buang hajat di tempat terbuka (menghadap Kakbah tanpa penghalang) antara lain bahwa ia akan disaksikan oleh orang-orang yang salat dan oleh malaikat. Selain itu, boleh jadi disebabkan akan tampak 'auratnya (As-Shun'ânî, 1960).

\section{KARAKTERISTIK MASYARAKAT MUSLIM KOTA SAMBAS DALAM MENENTUKAN ARAH KIBLAT DI RUMAH}

Di kalangan umat Islam, cara menentukan arah kiblat ternyata bermacam-macam, termasuk masyarakat muslim di Kota Sambas Kalimantan Barat. Berdasarkan penelitian ini, masyakat muslim di Kota Sambas dalam menentukan arah kiblat di rumah dapat dibagi menjadi beberapa kelompok.

1. Masyarakat yang menentukan arah kiblat dengan Kompas

Menurut Misbun (24 tahun), arah kiblat di rumahnya cukup sering diukur, hampir setiap tahun. Petugas yang mengukur adalah orang yang memang memiliki kemampuan khusus dalam penentuan arah kiblat, yang pada umumnya merupakan pengurus masjid terdekat. Adapun alat yang digunakan adalah menggunakan kompas. Sebelum dilakukan pengukuran, dilakukan terlebih dahulu perhitungan dengan rumus yang sudah biasa digunakan. Begitu pula menurut Dela (36 tahun). Di rumahnya, arah kiblat memang sudah ditentukan pada saat membangun rumah. Hasil pengukurannya pun sudah diberi tanda khusus sehingga sudah menjadi petunjuk arah kiblat yang tetap untuk pelaksanaan salat di rumah.

2. Masyarakat yang menentukan arah kiblat dengan berpatokan pada arah Matahari terbenam/Barat

Dari hasil interview kepada masyarakat di Kota Sambas, terdapat beberapa informan yang menjelaskan bahwa arah kiblat di rumahnya ditentukan dengan mengikuti posisi Matahari terbenam atau ke arah barat, seperti yang dinyatakan oleh Rusman (31 tahun), Ricad (41 tahun) dan beberapa informan lainnya. Di antara mereka ada yang sudah mengetahui bahwa adanya aplikasi di smartphone yang dapat digunakan untuk menentukan arah kiblat. Hanya saja media tersebut belum mereka gunakan. Beberapa di antaranya memang belum mengetahui adanya aplikasi tersebut sehingga mereka masih mengikuti kebiasaan keluarga atau masyarakat setempat dalam menentukan arah kiblat yakni menghadap ke barat atau berpatokan pada posisi Matahari terbenam.

Arah Matahari terbenam pada dasarnya tidak tetap, walaupun senantiasa berada di sebelah barat, namun selalu berubah secara perlahan-lahan setiap waktu. Jadi, penentuan arah kiblat yang berpatokan pada Matahari terbenam atau mengaraah ke barat merupakan cara yang keliru karena penyimpangannya akan cukup jauh. Arah kiblat Kota Sambas secara umum adalah $67,79^{\circ}$ dari utara ke arah barat atau memiliki nilai azimut sebesar $292^{\circ} 12^{\prime} 26^{\prime \prime}$. Jadi, masyarakat yang menentukan arah kiblat dengan berpatokan pada posisi Matahari terbenam atau ke arah barat akan menyimpang cukup jauh dan arahnya tidak konsisten. 
3. Masyarakat yang menentukan arah kiblat dengan memperkirakan arah kiblat masjid terdekat

Kelompok masyarakat ini memang tidak pernah mengukur arah kiblat di rumah mereka. Ada sejumlah alasan yang disampaikan oleh sejumlah informan. Pertama, mereka tidak mengukur arah kiblat di rumah karena yang bersangkutan sering melaksanakan salat di masjid. Yang kedua, ada informan yang beranggapan bahwa mengukur arah kiblat adalah tugas orang-orang yang berwenang (seperti pemerintah/kantor kementrian agama dll). Yang ketiga, mereka tidak menentukan arah kiblat di rumah mereka karena tidak memiliki kemampuan keilmuan di bidang tersebut sehingga memilih cara yang mudah yakni dengan menggunakan dugaan ke mana arah kiblat masjid terdekat.

Jumlah masyarakat yang menentukan arah kiblat dengan cara memperkirakan arah kiblat masjid terdekat cukup banyak. Hal ini seperti disampaikan oleh beberapa informan seperti Candra (24 tahun), Wara (23 tahun), Reza (26 tahun), Agus (46 tahun), Hasanah (47 tahun) dan sejumlah informan lainnya. Di antara informan menyebut metode ini dengan metode alami. Maksudnya adalah menggunakan naluri alamiah sehingga dengan keyakinannya dapat menentukan arah kiblat yang sudah sama dengan arah kiblat masjid terdekat. Alasan mereka menggunakan cara ini adalah karena letak rumah mereka tidak begitu jauh dari masjid sehingga arah kiblat masjid masih dapat diperkirakan. Umumnya mereka menggunakan patokan jalan raya yang dianggap lurus sehingga memudahkan mereka dalam memperkirakan arah kiblat sesuai dengan masjid yang terdekat. Pada umunya mereka tidak memberikan tanda khusus (seperti garis atau anak panah) ke mana arah kiblat di rumah.

Mereka juga umumnya belum mengetahui adanya aplikasi smartphone penunjuk arah kiblat. Salah satu alasannya adalah tidak memiliki smartphone. Namun, ada pula di antara mereka yang sudah mengetahui adanya aplikasi penunjuk arah kiblat, hanya saja mereka gunakan ketika bepergian atau menginap di hotel seperti yang diutarakan oleh Didi (49 tahun). Sedangkan untuk salat di rumah, mereka masih menggunakan naluri untuk menghadap kiblat sesuai dengan arah masjid terdekat. Cara menentukan arah kiblat seperti ini sebenarnya masih berpeluang untuk menyimpang dari arah kiblat yang seharusnya karena tidak ditentukan dengan cara yang benar dan masih bersifat dugaan. Selain itu, arah kiblat pada saat melaksanakan salat di rumah juga dapat berubah-ubah karena tidak diberi tanda khusus.

4. Masyarakat yang menggunakan aplikasi smartphone.

Aplikasi penunjuk arah kiblat seperti Arah Kiblat \& Waktu Shalat, Muslim, Muslim Ummah, Arah Kiblat, Cari Arah Kiblat, dan berbagai aplikasi lain yang dapat diunduh melalui smartphone pada umumnya sudah memenuhi ketepatan yang baik. Hal ini sudah dibuktikan peneliti yakni membandingkan perhitungan yang dilakukan peneliti sendiri dengan perhitungan pada aplikasi penunjuk arah kiblat tersebut. Hanya saja, berdasarkan kaidah ilmiah, beberapa aplikasi tersebut masih menggunakan dasar perhitungan segitiga bola (spherical trigonometry). Padahal, perhitungan yang paling akurat dan diakui oleh kalangan sains saat ini adalah perhitungan arah kiblat menggunakan formula Vincenty. Namun, hasil perhitungan antara kedua metode tersebut tidaklah berselisih terlalu signifikan karena hanya dalam orde menit busur, tidak sampai berselisih orde derajat. Dengan demikian, penggunaan smartphone sebagai penunjuk arah kiblat dapat dikatakan telah memadai dibandingkan dengan cara dugaan arah kiblat masjid terdekat atau menghadap ke arah posisi terbenam Matahari atau ke arah barat. Berikut adalah contoh aplikasi penunjuk arah kiblat yang masih menggunakan dasar perhitungan segitiga bola.

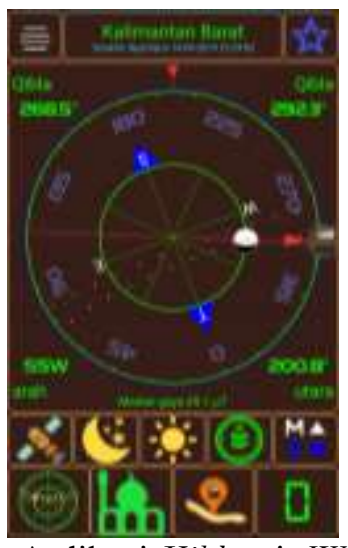

Gambar 6. Aplikasi Kiblat \&W Waktu Sholat 
Di antara informan yang menggunakan aplikasi penunjuk arah kiblat adalah Juli (51 tahun). Fitri (22 tahun), dan beberapa informan lain. Alasan mereka menggunakan aplikasi untuk menentukan arah kiblat adalah penentuan dengan cara ini sangat praktis dan dapat dilakukan sendiri tanpa harus menggunakan alat dan keahlian khusus. Di antara mereka yang menggunakan cara ini, ada yang memberikan tanda khusus seperti garis/anak panah, ada pula yang tidak. Bagi yang tidak memberikan tanda khusus, umumnya mereka hanya menentukan sekali saja arah kiblat di rumah, kemudian untuk melaksanakan salat berikutnya mereka mengandalkan naluri atau ingatan dalam menentukan arah berdasarkan hasil penentuan arah kiblat menggunakan aplikasi tadi.

Dari kategorisasi di atas, dapat diuraikan lebih jauh mengenai karakteristik masyarakat Kota Sambas dalam menentukan arah kiblat di rumah.

1. Pada umumnya masih menggunakan arah kiblat masjid terdekat

Cara seperti sebenarnya menjadi hal yang wajar karena masyarakat memang tidak memiliki kemampuan khusus dalam menentukan arah kiblat. Selain itu, terdapat pula masyarakat yang belum mengetahui adanya aplikasi penunjuk arah kiblat melalui smartphone. Ada pula yang sudah mengetahui, akan tetapi belum terdorong untuk menggunakannya karena sudah yakin dengan arah kiblat rumah mereka sama dengan arah kiblat masjid terdekat. Padahal dengan cara seperti ini, arah kiblat di rumah menjadi tidak akurat.

2. Pada umunya masyarakat tidak memberikan tanda khusus

Walaupun arah kiblat sudah ditentukan, baik melalui perhitungan, rashdul kiblat global, maupun menggunakan aplikasi penunjuk arah kiblat, jika tidak diberi tanda khusus maka akan menyebabkan arah kiblat menjadi tidak akurat dan dapat berubah-ubah sesuai dengan perkiraan. Oleh sebab itu, pemberian tanda khusus arah kiblat di rumah menjadi sangat penting setelah dilakukan pengukuran sehingga arahnya konsisten dan salat menjadi lebih khusyu.

3. Masyarakat pada umumnya masih menggunakan dugaan

Dugaan mengenai ke mana arah kiblat di rumah ini setidaknya ditandai oleh tiga hal.
Pertama, masyarakat cenderung menggunakan perkiraan arah masjid terdekat. Yang kedua, ada masyarakat yang mengarahkan kiblatnya ke posisi Matahari terbenam atau kea rah barat. Ketiga, masyarakat umumnya tidak memberikan tanda khusus sehingga arah kiblatnya dapat saja berubah-ubah atau tidak konsisten.

\section{PENUTUP}

\section{Simpulan}

Berdasarkan penelitian ini, disimpulkan bahwa masyarakat Kota Sambas dalam menentukan arah kiblat di rumah terbagi menjadi beberapa kelompok yaitu pertama, masyarakat yang menentukan arah kiblat dengan Kompas dengan melakukan perhitungan terlebih dahulu. Kedua, masyarakat yang menentukan arah kiblat dengan berpatokan pada arah Matahari terbenam/Barat. Ketiga, masyarakat yang menentukan arah kiblat dengan memperkirakan arah kiblat masjid terdekat. Keempat, masyarakat yang menentukan arah kiblat menggunakan aplikasi smartphone penunjuk arah kiblat.

Adapun karakteristik masyarakat Kota Sambas Kalimantan Barat dalam penentuan arah kiblat dalam pelaksanaan salat di rumah adalah: pertama, penentuan arah kiblat umumnya masih menggunakan perkiraan arah masjid terdekat. Kebiasaan ini menjadi cara yang paling umum digunakan oleh masyarakat. Kedua, pada umumnya, masyarakat tidak memberikan tanda khusus seperti garis atau tanda anak panah sebagai petunjuk arah kiblat di rumah. Ketiga, secara umum, masyarakat Kota Sambas dalam menentukan arah kiblat masih menggunakan dugaan karena umumnya tidak diberi tanda khusus dan menggunakan arah kiblat masjid terdekat. Sedangkan masyarakat yang mengukur atau menentukan arah kiblatnya dengan akurat jumlahnya relatif sedikit.

\section{Saran}

Berdasarkan hasil penelitian ini, masyarakat Kota Sambas Kalimantan Barat sangat membutuhkan informasi dan petunjuk yang benar tentang cara menghadap kiblat yang sesuai dengan kaidah-kaidah ilmiah. Oleh sebab itu, penulis menyarankan kepada pihak yang berwenang, seperti Majelis Ulama Indonesia dan Kementrian Agama untuk memberikan panduan kepada 
masyarakat Kota Sambas tentang bagaimana cara menentukan arah kiblat dengan benar.

\section{DAFTAR PUSTAKA}

'Awânah, Abû, (tt). Musnad Abû 'Awânah, Beirut: Dârul Ma'rifah, Maktabah Syamilah

Baihaqi, Ahmad bin al-Husain bin 'Ali bin Musa al-Khusrowjirdi al-Khurasani Abu Bakr. (2013). Al-Sunan al-Kubra, Beirut: Dar alKutub al-'ilmyyah, Maktabah Syamilah.

Badan Pusat Statistik, (2010). Peraturan Kepada Badan Pusat Statistik Nomor 37 Tahun 2010 Tentang Klasifikasi Perkotaan dan Perdesaan di Indonesia, Buku III, Cet-2.

Dukcapil, (2018). "Data Statistik Kependudukan Provinsi Kalimantan Barat", https://www.dukcapil.kalbarprov.go.id/st atistik/agama, diakses 9 April 2019.

Fakh Râzî, (tt). Tafsir Fakhr Rẫ̂́, Juz 2, Maktabah Syamilah

Fatahillah, Ahmad Ghazali Muhammad, (2017). Jami'u al- adillah Ila Ma'rifati Samtu al-Qiblah. Madura: Lafal.

Hambali, Slamet, (2013). Ilmu Falak Arah Kiblat Setiap Saat. Yogyakarta: Pustaka Ilmu.

(2012). Pengantar Ilmu Falak Menyimak Proses Pembentukan Alam Semesta, Banyuwangi : Bismillah Publisher.

Izzuddin, Ahmad, (2011). "Kajian terhadap Metode-Metode Penentuan Arah Kiblat dan Akurasinya", (Desertasi), Pascasarjana UIN Walisongo Semarang.

Kementrian Agama RI, (2017). Ephemeris Hisab Rukyat, Jakarta: Kementrian Agama RI

Marwadi, (2014). “Aplikasi Teori Geodesi dalam Perhitungan Arah Kiblat: Studi untuk Kota Banjarnegara, Purbalingga, Banyumas, Cilacap, Kebumen", Jurnal AlManahij Jurnal Kajian Hukum Islam, DOI: https://doi.org/10.24090/mnh.v8i2.416, Vol 8 No 2 (2014): 329-351, diakses 12 Maret 2019.

Munajjid, Syekh Muhammad Shalih, (2019). "Hukum Membangun Kloset Menghadap Kiblat", https://islamqa.info/id.
Muslim, Kori Lilie, (2017). "Nilai-Nilai Islam dalam Budaya dan Kearifan Lokal (Konteks Budaya Mingkabau", Fuaduna: Jurnal Kajian Keagamaan dan Kemasyarakatan, Volume 1 Nomor 1 Tahun 2017: 48, e-ISSN: 2614-8129, https://ejournal.iainbukittinggi.ac.id/inde x.php/fuaduna/ article/view/441/pdf, diakses 9 April 2019

Raharto, Moedji \& Dede Jaenal Arifin Surya, (2011). "Telaah Penentuan Arah Kiblat dengan Perhitungan Trigonometri Bola dan Bayang-Bayang Gnomon oleh Matahari", Jurnal Fisika Himpunan Fisika Indonesia, Volume 11 (1), Juni (2011), diakses 6 Maret 2018, https://anzdoc.com.

Rukyatul Hilal Indonesia (RHI), (2019). "Cara Menentukan Arah Kiblat", irhandiferianto.orgfree.com/arah_kiblat.p df.

Sugiyono, (2017). Metode Penelitian Kualitatif: untuke Penelitian yang bersifat Eksploratif, Enterpretif, Interaktif, dan Konstruktif, Bandung: Alfabeta.

Shun'ânî, Muhammad Ibnu Ismâ'îl Al-Amîr AlKahalânî, (1960). Kitab Subul As-Salâm Bab Âdâb Qadhâul Hâjah, Juz 1, Beirut: Maktabah Mushthofâ Al-Bâbi Al-Halbî, Maktabah Syamilah

Vincenty, T. (1975). "Direct and Inverse Solutions of Geodesics on the Ellipsoid Application of Nested Equations", Survey Review XXII.

Wikipedia, "Kabupaten Sambas", https://id.m.wikipedia.org/wiki/Kabupat en_Sambas.

"Sambas, Sambas", https://id.wikipedia.org/wiki/Sambas, S ambas.

"Suku Sambas", https://id.wikipedia.org/wiki/Suku_Sam bas. 